\title{
PHYSIOTHERAPISTS' KNOWLEDGE OF THE TRANSMISSION AND PREVENTION OF COMMUNICABLE DiSEASES
}

\begin{abstract}
With the world-wide increase of communicable diseases, adequate knowledge by health professionals of the transmission and prevention of these diseases is essential to ensure effective protection. The aim of this study was to determine whether practising physiotherapists' knowledge of the transmission and prevention of tuberculosis, hepatitis A, hepatitis B, hepatitis $C$ and HIV/AIDS was adequate to ensure effective protection.

G RO BLER L ${ }^{1}$, KLFYN HANS ${ }^{1}$, LUBBE A ${ }^{1}$, SMIT T ${ }^{1}$, RETIEF $C^{1}$, VICTOR D ${ }^{1}$, BESTER CJ ${ }^{2}$

1 Department of Physiotherapy and ${ }^{2}$ Department of Biostatistics, University of the Free State, Bloemfontein.

A descriptive study was conducted. One hundred and forty six practising physiotherapists in the Free State received questionnaires on which they had to indicate the relevant transmission and preventative measures for each disease. One hundred and three (70.5\%) questionnaires were returned. Points were allocated for the knowledge of transmission and preventative measures. The medians with respect to transmission were: tuberculosis $83 \%$, hepatitis A $58 \%$, hepatitis B 67\%, hepatitis C 75\% and HIV/AIDS 92\%. The medians with respect to preventative measures were: tuberculosis 57\%, hepatitis A 58\%, hepatitis B 77\%, hepatitis C 67\% and HIV/AIDS 71\%. The knowledge of transmission was better than the knowledge of preventative measures. An increase in the knowledge of practising physiotherapists in the Free State is needed to ensure their maximal protection against communicable diseases.
\end{abstract}

\section{KEY WORDS: TUBERCULOSIS, HEPATITIS, HIV/AIDS, KNOWLEDGE, TRANSMISSION, PREVENTION}

\section{INTRODUCTION}

Physiotherapists are constantly in contact with a variety of patients and diseases, and thus run an increased risk of infection. In South Africa, 1000 people die of tuberculosis every month (Collins, 2000), 1700 are infected with HIV daily (Orlovic, 2000) and roughly $60 \%$ of adults have been infected with hepatitis B (Yach \& Buthelezi, 1995).

A study by Buso et al (2000) reported that few South African doctors knew the correct diagnostic protocol for pulmonary tuberculosis. Doctors in a middle income county in China appeared to understand the transmission of hepatitis $\mathrm{B}$, but confused it with hepatitis A. Doctors who had not gained the village doctor certificate appeared to have the greatest need for further education and infor-

\section{CORRESPONDENCE TO:}

L Grobler

Department of Physiotherapy, University of the Free State,

PO Box 339,

Bloemfontein 9300 mation of hepatitis B seems to be theoretical and not practical (Clayton et al, 1993). An increase in knowledge of HIV/AIDS in physiotherapy and occupational therapy students led to a positive influence on their regard towards patients, but did not improve their willingness to work with these patients (Balogun et al, 1997). A previous study determined that the attitude of physiotherapists in Bloemfontein is positive towards treating HIV/AIDS patients although some moral questions were posed. More than half $(58 \%)$ of these physiotherapists did not have an adequate working knowledge of the preventative measures for HIV transmission (Barr et al, 1994).

The aim of the study was therefore to determine whether physiotherapists practising in the Free State have adequate knowledge of the transmission and prevention of tuberculosis, hepatitis $\mathrm{A}$, $\mathrm{B}$ and $\mathrm{C}$ and HIV/AIDS.

\section{METHODS}

A descriptive study was conducted. All practising physiotherapists in the Free
State were included. Addresses were obtained from the SA Physiotherapy Association (Free State), Private Practice Association, Provincial Head of Clinical Physiotherapists, telephone directories and personal enquiry. Participation was voluntary and confidentiality was ensured. The Ethics Committee of the Faculty of Health Sciences, University of the Free State (UFS) approved the study.

A questionnaire was compiled and consisted of the following segments: demographic information, general knowledge and knowledge regarding transmission and preventative measures of tuberculosis (TB), Hepatitis A-virus (HAV), hepatitis B-virus (HBV), hepatitis C-virus (HCV) and HIV/AIDS. Participants had to indicate whether a certain preventative measure was always essential, desirable, or never essential.

In Bloemfontein, questionnaires were delivered by hand and questionnaires were mailed to physiotherapists in the rest of the Free State. Stamped envelopes were included. 
To keep bias and variation to a minimum the following was done:

- Questionnaires were compiled under supervision of the Department of Biostatistics after a literature review and consulting with experts on communicable diseases and on compiling questionnaires. A pilot study was also conducted in which eight non-practising lecturers (Department Physiotherapy, UFS) completed the questionnaire.

- A covering letter attached to each questionnaire, explained that discussing or retrieving additional information to answer the questionnaire would influence the results.

The correct answers for the questions were obtained from various relevant sources (Collins, 1989; Benenson, 1990; Mandell et al, 1990; WHO Fact Sheets $\mathrm{WHO} / 204$ and WHO/164, 2000; and WHO vaccines, 2002).

Descriptive statistics, namely frequencies and percentages for categorical data, and means and standard deviations or medians and percentiles for continuous data were determined by the Department of Biostatistics, UFS.

An information leaflet with the relevant information as well as the results of the study was sent to all participants.
Table 1: Demographic information of participants $(n=103)$

\begin{tabular}{|c|c|}
\hline Male & $8(8 \%)$ \\
\hline Female & $95(92 \%)$ \\
\hline Mean age & $\begin{array}{l}30 \text { years } \\
\text { (range } 21-60)\end{array}$ \\
\hline Location of practice: & \\
\hline Bloemfontein & $69 \%$ \\
\hline Rest of Free State & $31 \%$ \\
\hline Type of practice: & \\
\hline Full-time private & $51 \%$ \\
\hline Part-time private & $15 \%$ \\
\hline Full-time hospital & $40 \%$ \\
\hline Part-time hospital & $16 \%$ \\
\hline Academic & $6 \%$ \\
\hline $\begin{array}{l}0 \text { ther (eg. School, } \\
\text { home consultations, } \\
\text { community) }\end{array}$ & $8 \%$ \\
\hline
\end{tabular}

\section{RESULTS}

One hundred and three $(70.5 \%)$ of the 146 questionnaires were returned. The demographic information is summarised in Table 1. The respondents were predominantly female $(92 \%)$ and practising in Bloemfontein $(69 \%)$, with a median of 7 years practical experience.

\section{Transmission}

Table 2 summarises the method of transmission of the relevant diseases.

Tuberculosis: All participants (103) answered the TB section, but one person marked all the options and was excluded. Six participants scored the maximum of $100 \%$ and 2 participants scored the minimum of $42 \%$. The participants who marked the option "other" did not specify anything except one who specified "contact with air". A large percentage of participants correctly knew that TB was transmitted via sputum $(84 \%)$ and nasopharyngeal secretions (78\%). A smaller percentage $(65 \%)$, however, marked that $\mathrm{TB}$ was transmitted via aerosols.

Hepatitis A: Twelve participants did not complete the HAV section and one participant marked all the options and was excluded. Two participants scored the maximum of $83 \%$ and one participant scored the minimum of $25 \%$. Three participants marked the option "other", but did not specify anything. The main route for HAV transmission is the faecal-oral route, but HAV is also transmitted via nasopharyngeal secretion, sputum and aerosols. Few participants, however, marked these routes (Table 2).

Table 2: Method of transmission of the relevant diseases

\begin{tabular}{|c|c|c|c|c|c|}
\hline \multirow[t]{2}{*}{ Method of transmission } & \multicolumn{5}{|c|}{ Chosen option (\% participants) } \\
\hline & $\begin{array}{l}\text { TB } \\
(n=102)\end{array}$ & $\begin{array}{l}\text { HAV } \\
(n=90)\end{array}$ & $\begin{array}{l}\text { HBV } \\
(n=95)\end{array}$ & $\begin{array}{l}\text { HCV } \\
(n=85)\end{array}$ & $\begin{array}{l}\text { HIV/ AIDS } \\
(n=101)\end{array}$ \\
\hline Faecal - oral & 26 & 69 & 55 & 39 & 45 \\
\hline $\mathrm{N}$ asopharyngeal secretions (without blood) & 78 & 32 & 31 & 18 & 20 \\
\hline A erosols & 65 & 22 & 17 & 8 & 6 \\
\hline Saliva (without blood) & 65 & 31 & 37 & 16 & 16 \\
\hline Urine (without blood) & 14 & 25 & 40 & 23 & 24 \\
\hline Blood & 27 & 53 & 79 & 67 & 99 \\
\hline N eedle pricks & 13 & 45 & 69 & 46 & 94 \\
\hline Sputum (without blood) & 84 & 38 & 39 & 21 & 22 \\
\hline Sweat & 4 & 15 & 11 & 5 & 6 \\
\hline Tears & 4 & 7 & 7 & 3 & 8 \\
\hline Faeces (without blood) & 17 & 42 & 37 & 28 & 31 \\
\hline Sexual secretions & 14 & 23 & 40 & 23 & 78 \\
\hline 0 ther (specify) & 6 & 3 & 10 & 5 & 14 \\
\hline
\end{tabular}

Shaded area $=$ Correct option 
Hepatitis B: Seven participants did not complete the HBV section and one participant marked all the options and was excluded. Nine participants scored the maximum of $92 \%$ and one participant scored the minimum of $25 \%$. Only $37 \%$ of the participants marked the correct options "sputum (without blood)" and 40\% marked "sexual secretions". Participants were more knowledgeable about the transmission routes "blood" $(79 \%)$ and "needle pricks" (69\%) [only $0.0004 \mathrm{ml}$ blood is needed for the transmission of $\mathrm{HBV}$ and physiotherapists have to be aware of the high risk involved].

Hepatitis C: Sixteen participants did not complete the HCV section and 2 participants marked all the options and were excluded. Ten participants scored the maximum of $100 \%$ and 4 participants the minimum of $42 \%$. The participants who marked "other" did not specify anything. Participants marked the correct transmission routes "blood" $(67 \%)$ and "needle pricks" (46\%), and many marked the incorrect options "faecaloral" (39\%) and "faeces (without blood)" (28\%). A lack of HCV knowledge could account for the many transmission options marked.

HIV/AIDS: All participants answered the HIV/AIDS section. Two participants marked all the options and were excluded. Twenty-three participants scored $100 \%$, one participant scored the minimum of
33\%. Those who marked the option 'other' did not specify anything.

\section{Preventative measures}

The preventative measures for hepatitis (HAV, HBV and HCV) transmission are summarised in Table 3 and for TB and HIV/AIDS in Table 4. The correct options are highlighted.

Hepatitis A: For HAV (Table 3), 8 of the 11 preventative measures are always necessary. The percentage participants that chose the correct "Always" option ranged from $64 \%$ to $92 \%$. Although "Desirable" was the correct option for the 3 remaining questions, most participants chose the "always" option (48\%

Table 3: Preventative measures for hepatitis transmission

\begin{tabular}{|c|c|c|c|c|c|c|c|c|c|c|c|c|}
\hline \multirow[t]{2}{*}{ Preventative measure } & \multicolumn{4}{|l|}{ HAV } & \multicolumn{4}{|l|}{ HBV } & \multicolumn{4}{|l|}{ HCV } \\
\hline & $\begin{array}{l}\text { Alw ays } \\
(\%)\end{array}$ & \begin{tabular}{|l|} 
Desirable \\
$(\%)$
\end{tabular} & $\begin{array}{l}\text { Never } \\
(\%)\end{array}$ & $n$ & \begin{tabular}{|l|} 
Alw ays \\
$(\%)$
\end{tabular} & \begin{tabular}{|l|} 
Desirable \\
$(\%)$
\end{tabular} & \begin{tabular}{|l|} 
Never \\
$(\%)$
\end{tabular} & $n$ & \begin{tabular}{|l|} 
Always \\
(\%)
\end{tabular} & \begin{tabular}{|l|}
$\begin{array}{l}\text { Desirable } \\
(\%)\end{array}$ \\
$\%$
\end{tabular} & $\begin{array}{l}\text { Never } \\
(\%)\end{array}$ & $n$ \\
\hline Washing hands & 92 & 8 & 0 & & 96 & 4 & 0 & 100 & 93 & 7 & 0 & 95 \\
\hline Disinfecting hands & 67 & 32 & 1 & 100 & 78 & 22 & 0 & 100 & 68 & 32 & 0 & 95 \\
\hline Wearing gloves & 58 & 38 & 4 & 99 & 81 & 18 & 1 & 101 & 61 & 36 & 3 & 94 \\
\hline $\begin{array}{l}\text { Wearing gloves if excretions } \\
\text { (urine and faeces) are present }\end{array}$ & 80 & 20 & 0 & 100 & 81 & 18 & 1 & 101 & 65 & 34 & 1 & 95 \\
\hline $\begin{array}{l}\text { Wearing gloves if visible } \\
\text { blood is present }\end{array}$ & 80 & 19 & 1 & 100 & 93 & 6 & 1 & 100 & 88 & 11 & 1 & 94 \\
\hline $\begin{array}{l}\text { Wearing gloves if saliva, } \\
\text { sputum and nasopharyngeal } \\
\text { secretions are present }\end{array}$ & 62 & 36 & 2 & 98 & 76 & 22 & 2 & 100 & 66 & 31 & 3 & 94 \\
\hline W earing a mask & 48 & 36 & 16 & 100 & 60 & 32 & 8 & 100 & 55 & 39 & 6 & 95 \\
\hline $\begin{array}{l}\text { Wearing a mask if infective } \\
\text { material can splash }\end{array}$ & 81 & 17 & 2 & 99 & 87 & 12 & 1 & 101 & & & & \\
\hline W earing a plastic apron & & & & & & & & & 44 & 51 & 5 & 94 \\
\hline $\begin{array}{l}\text { Wearing a plastic apron if } \\
\text { excretions (urine and faeces) } \\
\text { are present }\end{array}$ & 65 & 32 & 3 & 99 & 66 & 31 & 3 & 101 & 60 & 37 & 3 & 94 \\
\hline $\begin{array}{l}\text { Wearing a plastic apron } \\
\text { if saliva, sputum and } \\
\text { nasopharyngeal secretions } \\
\text { are present }\end{array}$ & & & & & 61 & 37 & 2 & 100 & 52 & 46 & 2 & 93 \\
\hline $\begin{array}{l}\text { Wearing a plastic apron if } \\
\text { infective material can splash }\end{array}$ & 73 & 25 & 2 & 100 & 81 & 18 & 1 & 101 & 71 & 28 & 1 & 94 \\
\hline $\begin{array}{l}\text { Wearing eye protection if } \\
\text { infective material can splash }\end{array}$ & & & & & 85 & 13 & 2 & 100 & & & & \\
\hline $\begin{array}{l}\text { Sterilise vectors (e.g. } \\
\text { stethoscope) after contact } \\
\text { with patient }\end{array}$ & 64 & 31 & 5 & 99 & 70 & 30 & 0 & 100 & & & & \\
\hline $\begin{array}{l}\text { Putting terminal phase } \\
\text { patient in a single room }\end{array}$ & & & & & & & & & 45 & 47 & 9 & 92 \\
\hline
\end{tabular}

Shaded area $=$ Correct option 
Table 4: Preventative measures for TB and HIV/ AIDS transmission

\begin{tabular}{|c|c|c|c|c|c|c|c|c|}
\hline \multirow[t]{2}{*}{ Preventative measure } & \multicolumn{4}{|l|}{ TB } & \multicolumn{4}{|c|}{ HIV/ AIDS } \\
\hline & $\begin{array}{l}\text { Always } \\
\text { (\%) }\end{array}$ & $\begin{array}{l}\text { Desirable } \\
(\%)\end{array}$ & $\begin{array}{l}\text { Never } \\
(\%)\end{array}$ & $n$ & $\begin{array}{l}\text { Always } \\
\text { (\%) }\end{array}$ & $\begin{array}{l}\text { Desirable } \\
(\%)\end{array}$ & $\begin{array}{l}\text { Never } \\
(\%)\end{array}$ & $n$ \\
\hline Washing hands & 97 & 3 & 0 & 100 & 91 & 9 & 0 & 101 \\
\hline Disinfecting hands & 65 & 34 & 1 & 102 & 72 & 25 & 3 & 101 \\
\hline Wearing gloves & 58 & 40 & 2 & 100 & 73 & 26 & 1 & 99 \\
\hline $\begin{array}{l}\text { Wearing gloves if } \\
\text { excretions (urine and faeces) } \\
\text { are present }\end{array}$ & 76 & 22 & 2 & 102 & 75 & 23 & 2 & 100 \\
\hline $\begin{array}{l}\text { Wearing gloves if visible } \\
\text { blood is present }\end{array}$ & 75 & 25 & 0 & 101 & 94 & 5 & 1 & 101 \\
\hline $\begin{array}{l}\text { Wearing gloves if saliva, } \\
\text { sputum and nasopharyngeal } \\
\text { secretions are present }\end{array}$ & 85 & 15 & 0 & 102 & 77 & 22 & 1 & 100 \\
\hline W earing a mask & 84 & 16 & 0 & 101 & & & & \\
\hline $\begin{array}{l}\text { Wearing a mask if infective } \\
\text { material can splash }\end{array}$ & & & & & 93 & 7 & 0 & 100 \\
\hline $\begin{array}{l}\text { Wearing a cap with } \\
\text { endo-tracheal suction }\end{array}$ & 52 & 39 & 9 & 100 & & & & \\
\hline $\begin{array}{l}\text { Wearing a cap if infective } \\
\text { material can splash }\end{array}$ & & & & & 61 & 29 & 10 & 98 \\
\hline Wearing a plastic apron & 40 & 54 & 6 & 101 & & & & \\
\hline $\begin{array}{l}\text { W earing a plastic apron } \\
\text { if excretions (urine and } \\
\text { faeces) are present }\end{array}$ & 49 & 47 & 4 & 101 & 67 & 29 & 4 & 100 \\
\hline $\begin{array}{l}\text { Wearing a plastic apron } \\
\text { if saliva, sputum and } \\
\text { nasopharyngeal secretions } \\
\text { are present }\end{array}$ & 64 & 34 & 2 & 101 & 61 & 37 & 2 & 101 \\
\hline $\begin{array}{l}\text { Wearing a plastic apron if } \\
\text { infective material can splash }\end{array}$ & 82 & 17 & 1 & 101 & 83 & 15 & 2 & 102 \\
\hline $\begin{array}{l}\text { Wearing eye protection if } \\
\text { infective material can splash }\end{array}$ & & & & & 89 & 9 & 2 & 102 \\
\hline $\begin{array}{l}\text { Sterilise vectors (e.g. } \\
\text { stethoscope) after contact } \\
\text { with patient }\end{array}$ & 70 & 27 & 3 & 99 & 67 & 31 & 2 & 100 \\
\hline $\begin{array}{l}\text { Putting terminal phase } \\
\text { patient in a single room }\end{array}$ & 57 & 40 & 3 & 100 & 42 & 40 & 18 & 102 \\
\hline
\end{tabular}

Shaded area $=$ Correct option

to $62 \%$ ). Three participants marked the "other" option, but did not specify anything.

Hepatitis B: For HBV (Table 3) 11 of the 13 preventative measures is always necessary. The percentage participants that chose the correct "Always" option ranged from $61 \%$ to $96 \%$. Although "Desirable" was the correct option for the remaining 2 questions, most participants chose the "always" option $(60 \%$ and $81 \%$ ). Only $17.8 \%$ and $32 \%$, respectively, chose the correct "desirable" option with "wearing gloves" and "wearing a mask". This indicates either a more practical approach of the participants, over caution, or a constant choice of the same option. Two participants marked the "other" option, but did not specify anything.

Hepatitis C: Eight participants did not complete the section for HCV (Table 3). Seven participants gave no reason, and one participant stated that he/she had no knowledge of the disease. Five participants marked the "other" option, but did not specify anything.

Tuberculosis: For TB (Table 4), only $2 \%$ of the participants marked the correct option of "never" for the question "wearing gloves when excretions (urine and faeces) are present". No participant marked the correct option "never" for the question "wearing gloves when visible blood is present". Five participants marked the "other" option, but only 2 specified the following: "wearing a mask and glasses", and "wearing glasses is desirable". 
Table 5: Participants' knowledge of transmission and prevention of communicable diseases

\begin{tabular}{|l|l|l|l|l|l|l|}
\hline Disease & \multicolumn{2}{l}{$\begin{array}{l}\text { Transmission } \\
\text { (\% correct answers) }\end{array}$} & \multicolumn{2}{l|}{$\begin{array}{l}\text { Prevention } \\
\text { (\% correct answers) }\end{array}$} \\
\hline & Minimum & Median & Maximum & Minimum & Median & Maximum \\
\hline TB & 42 & 83 & 100 & 21 & 57 & 71 \\
\hline HAV & 25 & 58 & 83 & 8 & 58 & 92 \\
\hline HBV & 25 & 67 & 92 & 15 & 77 & 100 \\
\hline HCV & 42 & 75 & 100 & 0 & 67 & 92 \\
\hline HIV/AIDS & 33 & 92 & 100 & 7 & 71 & 93 \\
\hline
\end{tabular}

HIV/AIDS: For HIV/AIDS (Table 4), 12 of the 14 preventative measures always need to be taken. The percentage of participants who chose the correct "Always" option varied from $42 \%$ to $94 \%$. Although the correct option was "desirable" for the remaining 2 preventative measures most participants chose the "Always" option. Only 26\% and $31 \%$, respectively chose the correct option of "wearing gloves" and "sterilisation of vectors (e.g. Stethoscope) after contact with patient". Two participants marked the option "other", but did not specify anything.

The minimum, median and maximum percentage of correct answers given for TB, HAV, HBV, HCV and HIV/AIDS are summarised in Table 5. For TB, HCV and HIV/AIDS the median percentage of correct answers for transmission was higher than that for prevention.

\section{DISCUSSION}

Knowledge of the method of transmission is in general better than that of preventative measures for the diseases studied (Table 5).

The median percentage for the knowledge of method of transmission for HIV/AIDS is $91.7 \%$. The high percentage of participants that marked blood (99\%) and needle pricks (94\%) could be ascribed to the large amount of publicity that HIV/AIDS receives. It is, however, strange that $45 \%$ of the participants marked faecal-oral as a method of HIV/AIDS transmission.

Responses with regard to preventative measures indicate a more practical approach of the participants, over caution, or a constant choice of the same option.

Many participants in private practice may feel that they do not often come into contact with the diseases and therefore that the diseases do not pose any real threat to them. This may be a possible explanation why their knowledge of method of transmission and preventative measures is not comprehensive. It is, however, imperative that physiotherapists protect themselves as these diseases have asymptomatic periods varying from two weeks to years.

The knowledge of communicable diseases could be reinforced by publishing the results and inclusion into the physiotherapy pre-graduate curriculum.

\section{CONCLUSION}

Tuberculosis, hepatitis A, B and C and HIV/AIDS are growing problems in South Africa. Knowledge of these diseases is needed to ensure optimal protection for the physiotherapist.

The study shows that the physiotherapist's knowledge of transmission and preventative measures of these diseases is relatively good, but not adequate to ensure their optimal protection.

\section{REFERENCES}

Balogun JA, Kaplan MT, Miller TM 1998 The effect of professional education on the knowledge and attitudes of Physical therapist and occupational therapist students about Acquired Immunodeficiency Syndrome. Physical Therapy 78(10): 1073-1082

Barr C, de Wet T, van Wijck V, Walters L 1994 'n Ondersoek na die houding en kennis van fisioterapeute met betrekking tot die behandeling van VIGS pasiente. Bloemfontein: Final year physiotherapy student script, University of the Free State

Benenson AS 1990 Control of communicable disease in man. Washington DC: American Public Health Association
Buso DL, Jinabhai CC, Hausler HP 2000 Knowledge, attitudes and practices of private doctors with respect to national TB control programme - a national survey. The Southern African Journal of Epidemiology and Infection 15:68-73

Clayton S, Yang H, Guan J, Lin Z, Wang R 1993 Hepatitis B control in China: Knowledge and practices among village doctors. American Journal of Public Health 83:16851688

Collins TFB 1989 Tuberculosis: Understanding and managing the disease: a handbook for medical students and general practitioners and senior nurses. Johannesburg: South African National Tuberculosis Association

Collins T 2000 TB - Are we losing the battle? South African Medical Journal 90(3): 237-238

Kirsch RE, Abdool Karim SS, Prozesky OW 1994 Why viral hepatitis? South African Medical Journal 84(8): 523

Mandell GL, Douglas R, Bennett JE 1990 Principles and practice of infectious diseases. New York: Churchill Livingstone

Orlovic D 2000 Tuberculosis in HIV - infected patients. Continual Medical Education 18(4): 330-335

WHO Information Fact Sheets 2000. Hepatitis B Fact Sheet WHO/204. Available at: http://www.who.int/inf-fs/en/fact204.html

WHO Information Fact Sheets 2000. Hepatitis C Fact Sheet WHO/164. Available at: http://www.who.int/inf-fs/en/fact164.html

WHO Vaccines, Immunization and Biologicals 2002. Hepatitis A vaccine. Available at: http://www.who.int/vaccines/ en/hepatisisa.shtml

Yach D, Buthelezi G 1995. Chapter 3. Health Status. In: South African Health Review, Part I. Imperatives for health systems reform. Available at: http://www.hst.org.za/sahr/ chap3.htm 